\title{
ECONOMICS
}

\section{Analysis of Farmers' Willingness to Adopt Genetically Modified Insect-resistant Rice in China}

\author{
by
}

\section{Ruomei Xu}

College of Economics and Management, Anhui Agricultural University

\section{Yanrui Wu}

Economics Discipline, Business School, University of Western Australia and

\section{Jingdong Luan}

College of Economics and Management, Anhui Agricultural University 


\title{
Analysis of Farmers' Willingness to Adopt Genetically Modified Insect-resistant Rice in China
}

\author{
Ruomei $\mathrm{Xu}^{1}$, Yanrui $\mathrm{Wu}^{2}$ and Jingdong $\operatorname{Luan}^{1 *}$ \\ ${ }^{1}$ College of Economics and Management, Anhui Agricultural University, Hefei, China \\ ${ }^{2}$ Business School, University of Western Australia, Perth, Australia \\ *The corresponding author (luanjingdong@ahau.edu.cn)
}

\begin{abstract}
:
Genetically modified (GM) crops, particularly GM grain crops, have been controversial since their commercialization in 1996. However, only a few studies have investigated farmers' attitudes toward adopting GM grain crops in China. This study explores farmers' willingness to adopt GM insect-resistant rice prior to its commercial release in China and determines the factors that affect farmers' prospective adoption decisions. The analysis is based on data collected by using a questionnaire. The results of econometric analyses show that increasing output and income, and simplicity in crop management, have positive effects on prospective adoption, whereas the high seed price of GM rice has a significantly negative effect. Health implications also have a significantly positive effect on the farmers' decision to adopt GM grain crops. A comparative analysis of ordered and binary probit models also demonstrates that farmers are more deliberate in their decisions when they have fewer choices.
\end{abstract}

Keywords: China, genetically modified insect-resistant rice, farmers' willingness to adopt, ordered probit model, probit model.

Forthcoming in China Agricultural Economic Review

Acknowledgments: The authors acknowledge the generous financial support from Anhui Agricultural University (2014zs01) and the Ministry of Education of China (10YJC790174). 


\section{Introduction}

The commercialization of genetically modified (GM) crops has rapidly increased since the first GM plant was born in 1983 and the first transgenic tomato was approved for market sale in 1994. Land use for GM crops has increased more than 100-fold, from 1.7 million hectares in 1996 to over 175 million hectares in 2013 (James, 2013). However, GM crops have become the subject of a debate that involves consumers, farmers, scientists, non-governmental organizations, and the biotechnology industry at large, among others. As growers, farmers are the suppliers of the GM crops. Therefore, their attitude toward adopting GM crops undoubtedly has a significant effect on the commercialization of GM crops, and studying their recognition and willingness is crucial in understanding how agricultural transgenic technology will be featured in the future of a country.

The literature on GM crop adoption consists of two main research streams: one stream concentrates on the adoption of already commercialized crops, and the other on the possible adoption of crops prior to their commercial release. The former stream consists of ex post studies, in which researchers conduct their analyses based on information collected from the actual behavior of farmers. This method is referred to as the revealed preference approach. The latter consists of ex ante studies, in which researchers conduct their analyses based only on the expected behavior of farmers through methods, such as contingent valuation (Gyau et al., 2009).

The literature on ex post adoption decisions is exemplified, for instance, by the study of Finger et al. (2009), who analyzed the crucial factors that determine patterns of adoption. Their results show that expectations of cost reduction and simplicity in crop management are the main drivers for farmers to adopt herbicide-tolerant soybeans (HTS). The authors also found that seed companies have a major role in providing farmers with initial information on HTS and in affecting their adoption decisions. Consmuller et al. (2010) analyzed the underlying factors that induce the regional adoption of bacillus thuringiensis (BT) maize MON810 in Germany. They found that the maize acreage per farm, regional infestation frequency of the European corn borer, and target pest of BT maize are the main drivers of the BT maize adoption. 
Huang et al. (2010) analyzed the factors that drive Chinese farmers to adopt BT cotton technology. Their study reveals that the price of cotton seed, availability of technology, and level of farmers' education are all statistically significant in the empirical analysis.

Studies on ex ante adoption decisions are also available. Breustedt et al. (2008) conducted an ex ante analysis of the adoption of GM oilseed rape in Germany based on choice experiments involving 202 arable farmers. The multinomial probit estimation reveals that the attributes of GM, such as gross margin, expected liability from cross-pollination, and flexibility in returning to conventional oilseed rape, significantly affect the likelihood of adoption. Neighboring farmers' attitudes toward GM crops, number of farmers and farm characteristics are also found to be significant determinants of the prospective adoption. Areal et al. (2012) examined farmers' willingness to adopt genetically modified herbicide-tolerant (GMHT) oilseed rape and GMHT maize prior to their commercial release in the European Union. The results show that positive attitude toward the adoption of GMHT crops stems from economic expectations, ease of use, and environmental benefits. Concerns about the technology itself and the negative social perception of adopting GM crops are the main reasons behind farmers' negative attitudes toward the adoption of GMHT crops. The authors also paid special attention to the effect of coexistence measures on farmers' willingness to adopt GMHT crops and found that such measures may hamper GMHT adoption $^{1}$. Xu et al. (2010) explored Chinese farmers' willingness to adopt the GM staple food crop prior to its commercial release based on 229 farmers in Hubei Province using the binomial logistic regression model. The results reveal that farmers' income level, part-time farming, education level, expected production output, input costs of pesticide and fertilizers, expected marketing difficulty, and risk of safety of transgenic staple foods are the potential factors that influence farmers' production intention of transgenic staple foods. Krishna et al. (2007) estimated farmers'

\footnotetext{
${ }^{1}$ According to EU regulations 1829/2003 and 1830/2003, each Member State of the European Union must define appropriate means for ensuring the separation of genetically modified (GM) and conventional food supply chains (Sausse et al., 2013; Skevas et al., 2010).
} 
willingness to pay for insect-resistant BT eggplant technology in India.

Previous studies mainly adopted GM non-staple food or fiber crops as examples to examine the determinants of adoption. These studies suggest that a number of factors affect farmers' decisions to adopt a new technology. These influential factors include economic considerations, social-demographic characteristics, government policies, and so on. However, a few studies have also investigated farmers' adoption decision for GM staple food crop production, such as rice or wheat, in an ex ante setting. Although Xu et al. (2010) examined the Chinese farmers' potential production intention of transgenic staple foods, the farmers' adoption willingness is divided only into two categories, namely adopt and reject. A binomial logistic regression model is also used. In an ex ante setting, farmers' potential adoption willingness can be divided into at least three categories, namely adopt, uncertain, and reject. As such, the present study aims to identify the key factors that affect farmers' decision to adopt GM BT rice prior to its commercial release, and the analysis differs from that of $\mathrm{Xu}$ et al. (2010) in both research approach and scope of the determinants of adoption.

The present study contributes to the literature on farmers' adoption decision in an ex ante setting (that is, prior to the commercial release of the staple food crop). In the next section, the determinants of adoption are analyzed, and the theoretical hypotheses are proposed. In Section 3, the econometric models are developed to identify the key influential factors and the issues related to data and variables are addressed. In Section 4, the econometric results are presented. In the last section, the conclusion of the study is presented.

\section{Determinants of adoption and theoretical hypotheses}

The theory of planned behavior (TPB) proposes that people's behavior can be predicted by weighing the potential determinants of behavior, including attitudes, subjective norms, and perceived behavioral control (Zhou, 2006). Based on TPB and previous studies, this study develops an analytical framework to examine the factors that influence farmers' decisions to adopt GM rice in China. The impact factors are shown in Fig. 1 and discussed in detail in the rest of this section. 


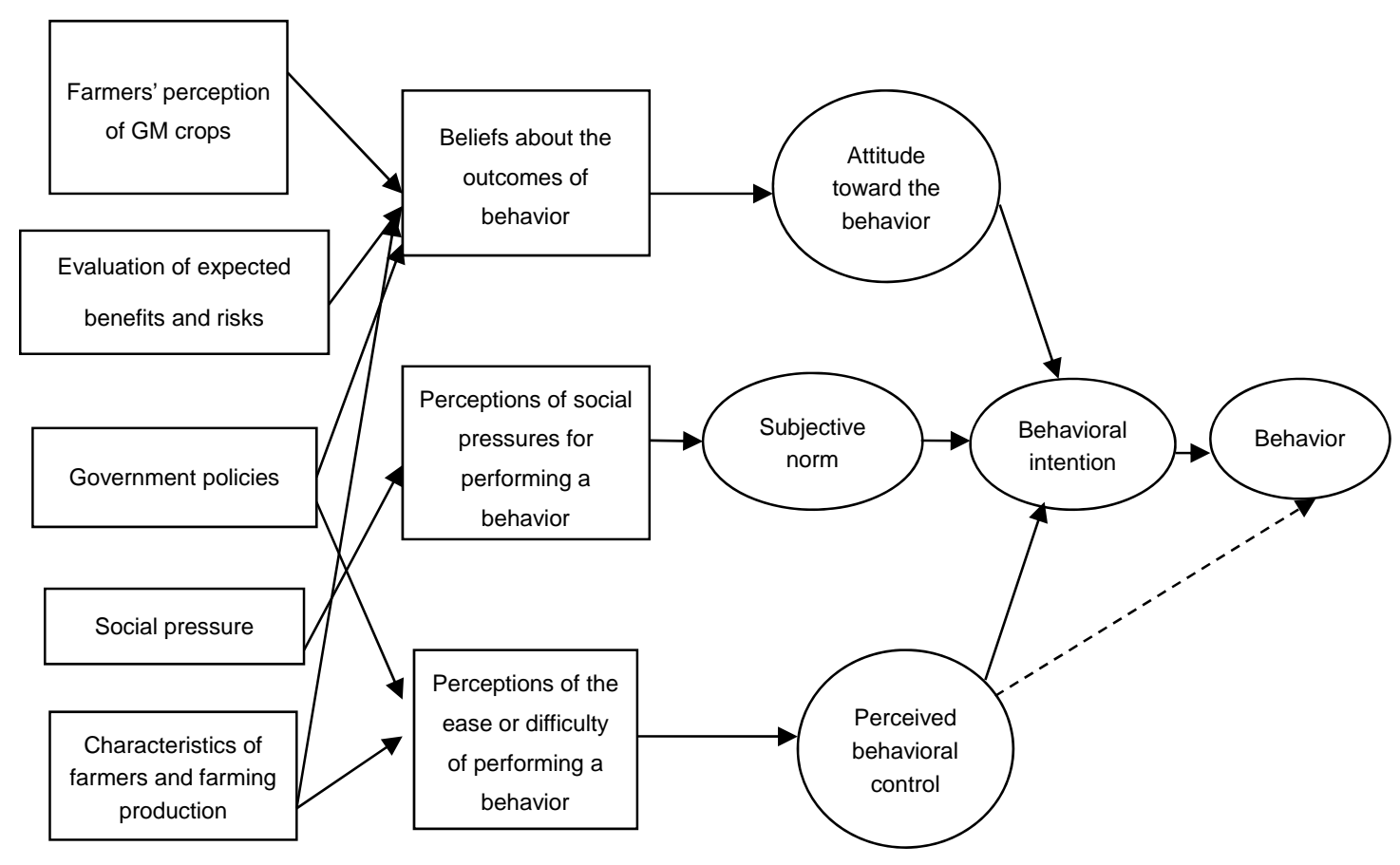

Source: Authors' own work.

Fig. 1. Analytical framework for the influential factors of farmers' decision

\subsection{Farmers' perception of GM crops}

Technological innovations in agriculture have typically been perceived as being riskier than traditional agricultural practices (Keelan et al., 2009). Farmers may give up, delay, or reduce the adoption of the new technology because of their lack of familiarity with it (Wang et al., 1996). Only after familiarizing themselves with the new technology would farmers consider whether to adopt it or not. Therefore, the following hypothesis is proposed:

H1: The more farmers know about GM crops, the more likely they are to hold positive attitudes toward GM crops and to plant GM rice.

\subsection{Farmers' evaluation of the expected benefits and risks of GM BT rice}

The increased output and net income from insect-resistance technology are reported because of the potential cost reduction resulting from lower expenditure on pesticides and labor (Sun et al., 2010; Demont et al., 2013). Aside from profitability, non-pecuniary benefits are also gained from greater flexibility and simplicity in crop management because farmers can reduce the time spent on spraying fields and controlling insects. With time saved, farmers may also increase their income from 
off-farm activities. Environmental and health benefits can also be achieved (Qaim et al., 2008) because of less insecticide exposure during spraying operations. For consumers, the reduction of insecticide application reduces contamination in water and food. However, potential environmental and health risks are also associated with GM insect-resistance crops (James et al., 2003; Xu et al., 2012). All these are important factors affecting both farmers' decision to adopt the new technology and consumers' willingness to accept BT crops. Consequently, the hypothesis is as follows:

H2: Farmers are more likely to adopt the new technology if the expected benefits of GM rice exceed the potential risks.

\subsection{Legislation and governmental policies associated with the cultivation of GM rice}

GM technology is typically perceived to be riskier than traditional agricultural practices. Farmers' attitudes toward adopting this technology are therefore also influenced by legislation and policies related to GM crops. Given that legislation is relevant to the coexistence policy, some studies have focused on the effect of mandatory separation distances on GM adoption (Areal et al., 2012; Skevas et al., 2010). Subsidies on superior seed varieties and policies supporting prices in rice production are favorable to farmers and are supposed to promote rice production in China. Therefore, the following hypotheses are proposed:

H3: Coexistence regulations have an effect on farmers' adoption decision.

H4: Subsidies on seeds and support price policies of GM rice have a positive effect on farmers' adoption.

\subsection{Social pressures of farmers}

TPB proposes that subjective norms can affect behavior intention. Subjective norms refer to individual perceptions of social pressures associated with certain behavior. The social pressures come from the groups with whom farmers frequently keep in touch during farming production. This study proposes that the social pressures on farmers come from the influence of neighbors, distributors, and 
government technicians. Thus, the following hypothesis is proposed:

H5: The recommendations of neighbors, distributors, and government technicians can affect farmers' adoption decision.

\subsection{Farmers' socioeconomic and rice-farming characteristics}

TPB states that farmers' socioeconomic and rice-farming characteristics may influence their attitude toward the behavior and perceived behavioral control. Previous studies have also demonstrated that farmers' socioeconomic and rice-farming characteristics can significantly affect their decision to adopt new technologies (Areal et al., 2012; Blazy et al., 2011; Keelan et al., 2009). Most studies have attempted to measure farmers' socioeconomic characteristics through their age, education, experience in cultivating rice, and share of off-farming income over family income. Farming characteristics are mainly proxied by farm size. Considering the small-scale features of rice plantation in China, the share of rice output for sale is also investigated in this study. Thus, the following hypothesis is proposed:

H6: Farmers' socioeconomic and rice-farming characteristics have an effect on their adoption decision.

\section{Methods}

\subsection{Farmer survey}

Given that this study aims to analyze farmers' adoption decisions toward GM rice prior to its commercial production, the data were collected only from the survey of potential GM rice growers rather than from other secondary sources. To maintain the quality of collected data, the final questionnaire was developed on the basis of a pilot survey, and the data were gathered through face-to-face interviews.

The questionnaire consists of five sections, and the survey is accordingly conducted in five steps. The first section collects the respondents' socioeconomic information and input-output of rice production in 2012. The second section focuses on the farmers' awareness level of GM crops. The farmers are asked about their understanding of GM crops. After this interview, an information sheet that describes 
the major risks and benefits of GM rice is provided to the farmers considering that most of them have only a minimal understanding of agricultural biotechnology according to the pilot survey results. They are then asked an open-ended question (that is "Please talk about your thoughts and feelings about GM rice"). In the fourth step, the farmers are asked whether they will cultivate GM rice or not. The respondents can choose their preference from three ordered alternatives: (a) I will not change to BT rice; (b) I am uncertain whether or not I should change to BT rice; and (c) I will change to BT rice. The last section includes specific questions related to influential factors, and the farmers are asked to give the reasons (including economic objectives, social pressures, and policies) that drive them to adopt GM rice according to the order of importance.

The respondents are from 20 villages of Luan, Hefei, Bengbu, Chuzhou, Anqing, Chaohu, Wuhu, and Maanshan regions in Anhui Province, China. These regions are designated as the advantageous districts of cultivating rice in the Anhui Advantageous Agricultural Products Regional Layout Planning (2008-2015) program published by the government. Fifty trained surveyors were selected from the 2011 and 2012 undergraduates of the Economics and Management School of Anhui Agricultural University to conduct the survey between July and December 2013. A random sample of 850 rice planters was selected, and an effective sample of 723 was used in the study. Considering the differences in the farmers' dialects in different villages, the selected surveyors' hometowns are located in the surveyed regions.

\subsection{Econometric model}

The farmers' willingness to cultivate BT rice is the dependent variable which has discrete values. Therefore, the qualitative response model is appropriate. The approach is either a multinomial or a binary model in the existing studies on GM adoption. This study considers both ordered and binary probit models for comparative analyses and the robustness of the estimated results is also checked.

(1) Ordered probit model

The respondents are asked to choose one answer from three options. The integers 
$(1,2$, and 3) represent the farmers' three alternative choices respectively: "I will not change to cultivate GM rice", "I am uncertain in deciding whether or not to adopt GM rice", and "I will change to cultivate GM rice". Therefore, the dependent variable $Y_{i}$ is an ordered response variable and an ordered probit model is appropriate.

Following Greene (2011), the ordered probit model can be expressed as follows:

$$
Y_{i}^{*}=X_{i}^{\prime} \beta+\varepsilon_{i} \quad i=1, \ldots, N \text { farmers }
$$

where $Y_{i}{ }^{*}$ is an unobserved latent variable, $X_{i}$ is the vector of the influential factors, $\beta$ is the vector of the parameters to be estimated which are associated with the explanatory variables, and $\varepsilon_{i}$ represents the unobservable factors and is assumed to be independently and normally distributed with a mean of 0 and standard deviation of 1 .

To ensure that all the probabilities are positive, the relationship between the latent variable $Y_{i}{ }^{*}$ and the observable $Y_{i}$ is defined as follows:

$$
\begin{gathered}
Y_{i}=1, \text { if } \quad Y_{i}^{*} \leqslant c_{1} \\
Y_{i}=2, \text { if } \quad c_{1}<Y_{i} * \leqslant c_{2} \\
Y_{i}=3 \text {, if } Y_{i} *>_{c_{2}}
\end{gathered}
$$

The $c_{1}$ and $c_{2}$ are the unknown ordered threshold parameters to be estimated with the unknown coefficient $\beta$. The probability of the dependent variable $Y$ assuming various possible values is as follows:

$$
\begin{gathered}
P(Y=1 \mid X)=F\left(c_{1}-X_{i}^{\prime} \beta\right) \\
P(Y=2 \mid X)=F\left(c_{2}-X_{i}^{\prime} \beta\right)-F\left(c_{1}-X_{i}^{\prime} \beta\right) \\
P(Y=3 \mid X)=1-F\left(c_{2}-X_{i}^{\prime} \beta\right)
\end{gathered}
$$

where $F$ indicates a cumulative normal distribution.

Meanwhile, the partial derivatives of $P(y=1 \mid X)$ and $P(y=3 \mid X)$ are obtained:

$$
\begin{gathered}
\frac{\partial P(Y=1)}{\partial X}=-f\left(c_{1}-X_{i}^{\prime} \beta\right) \beta \\
\frac{\partial P(Y=2)}{\partial X}=\left[f\left(c_{1}-X_{i}^{\prime} \beta\right)-f\left(c_{2}-X_{i}^{\prime} \beta\right)\right] \beta
\end{gathered}
$$




$$
\frac{\partial P(Y=3)}{\partial X}=f\left(c_{2}-X_{i}^{\prime} \beta\right) \beta
$$

where $f($.$) indicates the density function of \varepsilon$. The outcomes of the partial derivatives show that the marginal effects of the explanatory variables on the probabilities are not equal to the coefficient $\beta$. The direction of change in the probability $P(Y=1)$ when $X$ changes is the opposite of the sign of $\beta$, whereas the direction of change in the probability $P(Y=3)$ when $X$ changes is identical to the sign of $\beta$. The direction of change in the probability $P(Y=2)$ when $X$ changes is ambiguous.

\section{(2) Binary probit model}

The main difference between ordered and binary probit models is the dependent variable. In the binary probit model, the dependent variable $Y_{i}$ is the binary response variable, with a value of 1 representing "farmers will change to cultivating GM rice" and a value of 0 representing "farmers will not change to cultivating GM rice".

Following Greene (2011), the probit model can be determined by

$$
Y_{i}^{*}=c+X_{i}^{\prime} \beta+\varepsilon_{i} \quad i=1, \ldots, N \text { farmers }
$$

Similarly, $Y_{i}^{*}$ is an unobserved latent variable; $X_{i}$ is the vector of the influential factors; $\beta$ is the vector of the parameters to be estimated and is associated with the explanatory variables; $\varepsilon i$ represents the unobservable factors and is assumed to be independently and normally distributed with a mean of 0 and standard deviation of 1 ; and $c$ is constant.

The relationship between the latent variable $Y_{i}{ }^{*}$ and the observable $Y_{i}$ is defined as follows:

$$
\begin{gathered}
Y_{i}=1, \text { if } Y_{i}^{*}>0 \\
Y_{i}=0, \text { if } \quad Y_{i}^{*} \leq 0
\end{gathered}
$$

\section{3 Specification of variables}

Based on the discussion of theoretical hypotheses in Section 2, the explanatory variables consist of five types of factors. A number of indexes are used to describe 
these factors: (1) "Output, crop management, seed price, health impact, and environment impact" represent the factor "farmers' evaluation of the expected benefits and risks of GM BT rice"; (2) "Seed subsidies, price support, and coexistence" represent the factor "legislation and governmental policies associated with cultivation of GM rice"; (3) "Government technicians, neighbors, and distributors" represent the factor "social pressures of farmers"; (4) "Sex, age, education, per capita income, and nonfarm income share" represent the factor "socioeconomic characteristics of farmers"; and (5) "Size and share of rice sale" represent the factor "characteristics of rice farming". The definitions and corresponding assignments of all these explanatory variables are shown in Table1.

\section{Results and discussion}

\subsection{Descriptive statistics}

(1) Farmers' willingness to adopt GM BT rice

According to the survey, approximately $35.5 \%$ of the respondents will adopt the GM BT rice, and more than half are uncertain. By contrast, only $9.7 \%$ of the respondents definitively say that they will not change to adopt the new rice variety. Therefore, most farmers have a wait-and-see attitude toward their adoption decision. In a study on farmers' attitudes toward GM crops in Scotland using Q method, Hall (2008) presented the similar conclusion that farmers are apparently willing to wait, either to be convinced of the benefits of the technology or to be convinced of its potential risks. 
Table1 Definitions of independent variables and summary statistics

\begin{tabular}{|c|c|c|c|}
\hline & Variables & Definition & Assignment \\
\hline & Perception & $\begin{array}{l}\text { Farmers' awareness level } \\
\text { toward GM crops }\end{array}$ & $\begin{array}{l}\text { Never heard }=1 \text {, only heard }=2 \text {, better } \\
\text { understand }=3 \text {, very familiar }=4\end{array}$ \\
\hline \multirow{5}{*}{$\begin{array}{l}\text { farmers' } \\
\text { evaluation } \\
\text { of the } \\
\text { expected } \\
\text { benefits } \\
\text { and risks } \\
\text { of GM BT } \\
\text { rice }\end{array}$} & Output & $\begin{array}{l}\text { It guarantees higher output } \\
\text { and income }\end{array}$ & $\begin{array}{l}\text { Completely unimportant }=1 \text {, unimportant }= \\
2 \text {, uncertain }=3 \text {, } \\
\text { quite important }=4 \text {, very important }=5\end{array}$ \\
\hline & $\begin{array}{l}\text { Crop } \\
\text { management }\end{array}$ & It makes cultivation easier & $\begin{array}{l}\text { Completely unimportant }=1 \text {, unimportant }= \\
2 \text {, uncertain }=3 \text {, } \\
\text { quite important }=4 \text {, very important }=5\end{array}$ \\
\hline & Seed price & $\begin{array}{l}\text { Seed price is higher than } \\
\text { traditional seeds }\end{array}$ & $\begin{array}{l}\text { Completely unimportant }=1 \text {, unimportant }= \\
2 \text {, uncertain }=3 \text {, } \\
\text { quite important }=4 \text {, very important }=5\end{array}$ \\
\hline & Health impact & Health benefits and risks & $\begin{array}{l}\text { Completely unimportant }=1 \text {, unimportant }= \\
2, \text { uncertain }=3, \\
\text { quite important }=4 \text {, very important }=5\end{array}$ \\
\hline & $\begin{array}{l}\text { Environment } \\
\text { impact }\end{array}$ & $\begin{array}{l}\text { Environmental benefits and } \\
\text { risks }\end{array}$ & $\begin{array}{l}\text { Completely unimportant }=1 \text {, unimportant }= \\
2, \text { uncertain }=3, \\
\text { quite important }=4 \text {, very important }=5\end{array}$ \\
\hline \multirow{2}{*}{$\begin{array}{l}\text { legislation } \\
\text { and } \\
\text { government } \\
\text { al policies } \\
\text { associated } \\
\text { with }\end{array}$} & $\begin{array}{l}\text { Seed } \\
\text { subsidies }\end{array}$ & $\begin{array}{l}\text { Governmental subsidies on } \\
\text { superior seeds }\end{array}$ & $\begin{array}{l}\text { Completely unimportant }=1 \text {, unimportant }= \\
2 \text {, uncertain }=3, \\
\text { quite important }=4 \text {, very important }=5\end{array}$ \\
\hline & Price support & $\begin{array}{l}\text { Price support policy for GM } \\
\text { BT rice }\end{array}$ & $\begin{array}{l}\text { Completely unimportant }=1 \text {, unimportant }= \\
2 \text {, uncertain }=3 \text {, } \\
\text { Quite important }=4 \text {, very important }=5\end{array}$ \\
\hline
\end{tabular}




\begin{tabular}{|c|c|c|c|}
\hline $\begin{array}{l}\text { cultivation } \\
\text { of GM rice }\end{array}$ & Coexistence & $\begin{array}{l}\text { Mandatory } \\
\text { distances }\end{array}$ & $\begin{array}{l}\text { Completely unimportant }=1 \text {, unimportant }= \\
2 \text {, uncertain }=3 \text {, quite important }=4 \text {, very } \\
\text { important }=5\end{array}$ \\
\hline \multirow{3}{*}{$\begin{array}{l}\text { social } \\
\text { pressures of } \\
\text { farmers }\end{array}$} & $\begin{array}{l}\text { Government } \\
\text { technicians }\end{array}$ & $\begin{array}{l}\text { Government technicians' } \\
\text { recommendation for adoption } \\
\text { or not }\end{array}$ & $\begin{array}{l}\text { Completely unimportant }=1 \text {, unimportant }= \\
2, \text { uncertain }=3 \text {, quite important }=4 \text {, very } \\
\text { important }=5\end{array}$ \\
\hline & Neighbors & $\begin{array}{l}\text { Neighbors' recommendation } \\
\text { for adoption or not }\end{array}$ & $\begin{array}{l}\text { Completely unimportant }=1 \text {, unimportant }= \\
2 \text {, uncertain }=3 \text {, Quite important }=4 \text {, very } \\
\text { important }=5\end{array}$ \\
\hline & Distributors & $\begin{array}{l}\text { Distributors' recommendation } \\
\text { for adoption or not }\end{array}$ & $\begin{array}{l}\text { Completely unimportant }=1 \text {, unimportant }= \\
2 \text {, uncertain }=3, \\
\text { quite important }=4 \text {, very important }=5\end{array}$ \\
\hline \multirow{5}{*}{$\begin{array}{l}\text { socioecono } \\
\text { mic } \\
\text { characterist } \\
\text { ics of } \\
\text { farmers }\end{array}$} & Sex & Sex of farmers & Female $=0$, male $=1$ \\
\hline & Age & Age of farmers (years) & Survey data \\
\hline & Education & $\begin{array}{l}\text { Formal education of farmers } \\
\text { (years of schooling) }\end{array}$ & Survey data \\
\hline & $\begin{array}{l}\text { Per capita } \\
\text { income }\end{array}$ & $\begin{array}{l}\text { Per capita annual household } \\
\text { income (million yuan) }\end{array}$ & $\begin{array}{l}\text { Authors' own calculations according to } \\
\text { survey data }\end{array}$ \\
\hline & $\begin{array}{l}\text { Nonfarm } \\
\text { income share }\end{array}$ & $\begin{array}{l}\text { Share of off-farming income } \\
\text { over total family income }\end{array}$ & $\begin{array}{l}\text { No off-farming income }=1 \text {, share }<50 \%=2 \text {, } \\
\text { share } \geq 50 \%=3\end{array}$ \\
\hline \multirow{2}{*}{$\begin{array}{l}\text { characterist } \\
\text { ics of rice } \\
\text { farming }\end{array}$} & Size & The size of rice $(\mathrm{mu})$ & Survey data \\
\hline & $\begin{array}{l}\text { Share of rice } \\
\text { sale }\end{array}$ & $\begin{array}{l}\text { Share of rice to be sold over } \\
\text { total output }\end{array}$ & $\begin{array}{l}\text { No rice to be sold }=1,0 \%-50 \%=2,51 \%- \\
80 \%=3, \geq 80 \%=4\end{array}$ \\
\hline
\end{tabular}

Source: Authors' own work 
(2) Farmers' perception of GM crops

Fig. 2 shows that $38.8 \%$ of the respondents have not heard of any GM crop; $44.5 \%$ respondents have only heard of GM products, but known nothing about them; only $0.3 \%$ respondents declare that they knew much about GM products; and 16.4\% respondents think they had some understanding of GM products. Thus, the percentage of farmers who have very limited knowledge about GM crops is high. Hou et al. (2012) reported similar observations about farmers' knowledge of GM crops.

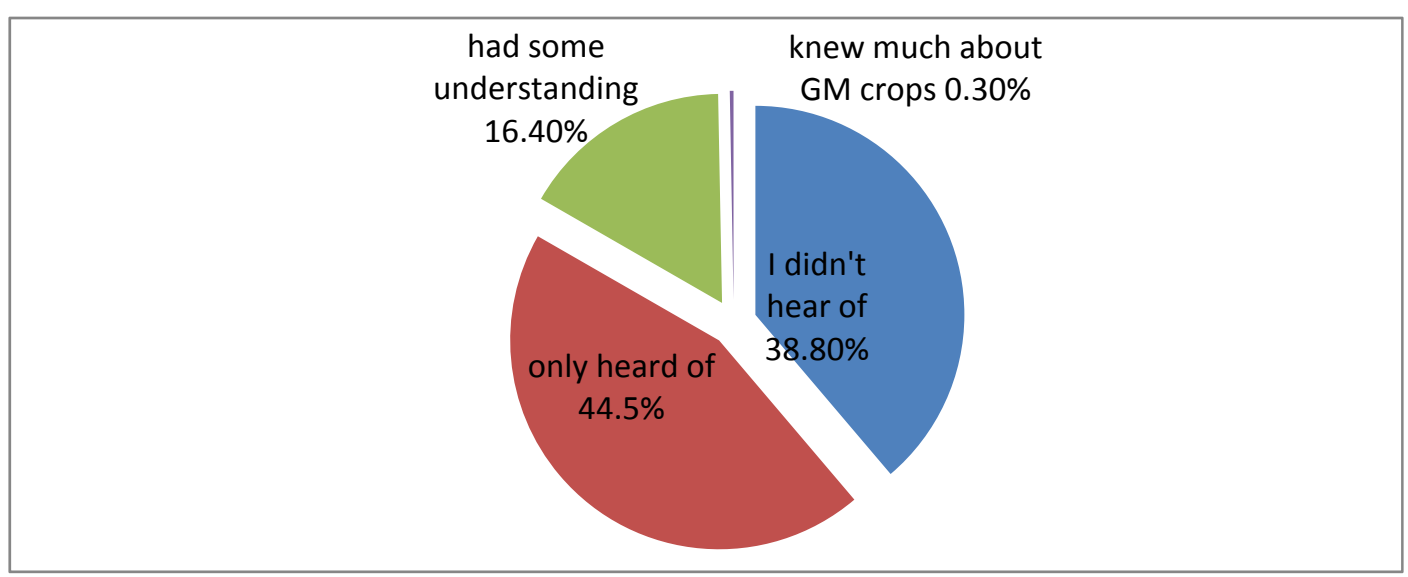

Source: Authors' own estimates

Fig. 2. Response percentages for the perception of GM crops

(3) Farmers' socioeconomic characteristics

Table 2 shows that the structural features of farmers indicate that male respondents are the dominant group, accounting for $78.6 \%$ of the total and that $81.9 \%$ of the respondents are 36 to 60 years old, that is, middle-aged and elderly people are the dominant group. Approximately $80.7 \%$ of the respondents have not received high school or above education; the respondents with the share of off-farming income over total family income above $50 \%$ are the dominant group, accounting for $81.6 \%$ of the total. All of the respondents have rich and long farming experiences because they are inhabitants of the major rice-producing region of the country. 
Table 2 Characteristics of the sample farmers

\begin{tabular}{llc}
\hline Demographic variable & Category & Percentage (\%) \\
\hline Sex & Men & 78.6 \\
& Women & 21.4 \\
Age (years) & Up to 35 & 7.4 \\
& $36-45$ & 30.9 \\
& $46-60$ & 51.0 \\
Education & Older than 60 & 10.7 \\
& Elementary school or below & 42.6 \\
Nonfarm income share & Middle school & 38.1 \\
& High school or above & 19.3 \\
& $0 \%$ & 9.6 \\
& $0 \%-50 \%$ & 8.8 \\
\hline
\end{tabular}

Source: Authors' own estimates

\section{(4) Characteristics of rice farming}

The survey shows that the average acreage of rice is only $6.5 \mathrm{mu}$. Table 3 shows that the respondents with rice acreage below $20 \mathrm{mu}$ account for $94.9 \%$ of the total, indicating that rice cultivation is predominantly small scale. However, most of the respondents still sold rice in the past. Given that most of the households are small-scale, it is unclear why they still have rice for sale. One reason may be that the farmers demand a small amount of rice because mainly elderly people and children are left in the villages given the continuous urbanization of China. Another reason may be due to the fact that farmers are willing to buy rice that tastes better or differently. Notably, $93.8 \%$ of the respondents cultivate rice once a year. With regard to the frequency of pesticides, the highest is three to five times, accounting for $47.1 \%$ of the total; the second highest is below three times, accounting for $38.8 \%$ of the respondents; and six times and above account only for $14.1 \%$ of the total. 
Table 3 Characteristics of rice farming

\begin{tabular}{llc}
\hline Statistical indicators & Category & Percentage \\
\hline Rice area (mu) & $(0,20]$ & $94.9 \%$ \\
& $(20,40]$ & $4.23 \%$ \\
Frequency of pesticides (times) & $(40,60)$ & $0.85 \%$ \\
& $0-3$ & 38.8 \\
Whether or not the farmer rents land & $3-5$ & 47.1 \\
from other farmers & above 5 & 14.1 \\
Share of rice to be sold over total & no & 16 \\
output (\%) & $0.00 \%$ & 84 \\
& $(0,50 \%]$ & 21.6 \\
Rice types & $(50,80 \%]$ & 32.4 \\
& $(80,100 \%)$ & 27.8 \\
& growing rice one once a & 18.2 \\
& year & 93.8 \\
& growing rice double once a & 6.2 \\
\hline
\end{tabular}

Source: Authors' own estimates

\subsection{Results of econometric estimation}

Both the ordered and binary probit models are estimated using Eviews 6.0, and the estimation results are presented in Table 4. Not all the independent variables were entered in the econometric models. First, the variables with small variation in their values, such as age, nonfarm income share, size, and perception, are excluded from the model. Then, per capita income is not included because too few respondents answered this question in the survey. Seed subsidies and price support are also not included because farmers believe the present measures do little to promote rice cultivation in practice. This finding is consistent with that of Zhan (2012), who proposed that the effects of price support are relatively weak in regions where grain production scale is smaller and the farmland is divided into many small blocks. Finally, coexistence is not factored into the model because of the lack of specific measures in China. Therefore, hypotheses 1, 3, and 4 cannot be verified because of insufficient data. 


\subsubsection{Results from an ordered probit model}

The model is statistically significant at the $1 \%$ significance level based on the likelihood ratio test. Two threshold values increase progressively and significantly. These tests indicate that the model has satisfactory explanatory power. Based on the analysis in Section 3.2, the sign of a parameter reveals the relationship between the explanatory variable and the willingness of adoption. The detailed analyses of each influential factor are as follows:

(1) Output, crop management, seed price, and health impact all have a significant effect on farmers' adoption decision toward GM rice.

The estimated coefficients of output, crop management and health impact are positive and statistically significant. The coefficient of seed price is also statistically significant, and its sign is negative. These results support hypothesis 2: "Farmers are more likely to adopt the new technology on the condition that the expected benefits of GM rice exceed the potential risks." However, environmental impact is statistically insignificant, indicating that farmers are less concerned with environmental benefits than they are with economic benefits. Health and economic benefits are generally crucial to the farmers' decisions. This finding is consistent with that of Chong (2005), who stated that economic benefits, safety concerns, and accountability are the most salient factors to Indian farmers' perception of the risks and benefits of BT eggplant. In contrast, in a survey on adopters and non-adopters among Illinois farmers, Guehlstorf (2008) found that risk is the main indicator that influences farmers' decision to adopt new, emerging, and contested agricultural technologies and that the "risks of superweeds and excessive pesticide use," which reflect environmental concerns, has a significant influence on farmers' perceived risk of GM technology.

(2) Social pressures have no effect on farmers' adoption decision toward GM rice

All the coefficients of the variables are statistically insignificant, which is contrary to hypothesis 5. Surprisingly, distributors' recommendation has a negative sign, which is unexpected. The potential reason may be that farmers distrust the 
dealers. According to Liu (2010), some seed markets appear to be disorderly, and some growers suffered badly from poor quality of seeds in recent years. These directly hurt the farmers' benefits.

(3) Part of the farmers' socioeconomic and rice-farming characteristics has a significant effect on their adoption decision toward GM rice

Among the variables, only education is found to be significant at the $5 \%$ significance level. The sign of the coefficient is also positive, which indicates that farmers with a higher educational level are more willing to cultivate GM rice. However, age is statistically insignificant. In the previous literature, Areal (2012) found that the variables of age, education, and income are insignificant. Keelan (2009) found that age, education, and off-farm income are insignificant. However, Xu (2010) obtained contrary conclusions and found that education, annual income per person in family, and share of off-farming income have a significantly negative effect.

Share of rice sale has a significant and positive effect on the decision to adopt. Thus the more rice the farmers sell, the higher the probability of them adopting the new technology is. Large households are therefore predicted in this study to be more willing to cultivate GM rice because the share of rice to sale is theoretically positively correlated with the farm size. In previous research, Keelan (2009) found that the early adopters of GM technology in Ireland are farmers with large farm acreage, indicating that the size of the farm has a positive and significant effect on the adoption behavior of farmers. Areal (2012) found that farm size is not one of the determinants of a farmer's willingness to adopt GMHT OSR/GMHT maize in the European Union, which is contrary to the conclusion here.

\subsubsection{Results based on the binary probit model}

The likelihood ratio test indicates that the binary probit model generally fits well. The estimated coefficients of the explanatory variables are all statistically different from zero, except for distributor and share of rice sale. The detailed analyses of each influential factor are as follows: 
(1) All variables about "expected benefits and risks of GM BT rice" have a significant effect on farmers' adoption decision toward GM rice. Table 4 shows that all variables, particularly output, seed price, and health impact, are statistically significant at the $1 \%$ significance level, which indicates that farmers take the health and economic benefits of GM rice very seriously.

(2) Government technicians' and neighbors' recommendations have a significant effect on farmers' adoption decision toward GM rice. The coefficients of government technician and neighbor are positive and statistically significant, which indicates that government technicians' recommendation and neighbors' attitude of adoption will increase the probability of farmers planting GM rice. Similarly, the estimated coefficient of distributor is not statistically significant.

(3) Some of the farmers' socioeconomic and rice-farming characteristics have a significant effect on their adoption decision toward GM rice. With regard to the impact of the farmers' socioeconomic and rice-farming characteristics on the farmers' decision toward GM rice, existing literature provides different conclusions. Large differences between the results of ordered and binary probit models are also observed. The coefficient of age is statistically significant, aside from education. The negative sign of the age coefficient indicates that the older the farmers are, the less likely they will plant GM rice. Similarly, the coefficient of education is significant at the $1 \%$ significance level. However, share of rice sale is insignificant.

\subsubsection{Comparative analyses of the results based on the ordered and binary probit} models

A comparison between the two models shows that the estimated results of output, crop management, seed price, health impact, and education are robust across all the models in Table 4. The number of significant variables in the binary probit model is also greater than that in the ordered probit model, which illustrates that farmers are 
more deliberate in the face of fewer choices. The environmental benefits and risks of GM rice also significantly affect farmers' willingness of adoption in the probit model.

Table 4 Estimation results of the probit and ordered probit models

\begin{tabular}{lcccc}
\hline & \multicolumn{2}{c}{ Ordered probit model } & \multicolumn{2}{c}{ Probit model } \\
\cline { 2 - 5 } Explanatory & coefficient & Z-Statistic & coefficient & Z-Statistic \\
Variables & & & & \\
\hline Output & $0.252^{* * *}$ & 2.58 & $0.537^{* * *}$ & 3.156 \\
Crop management & $0.216^{* * *}$ & 2.674 & $0.180^{*}$ & 1.669 \\
Seed price & $-0.145^{*}$ & -1.813 & $-0.387^{* * *}$ & -3.359 \\
Environment impact & 0.079 & 1.114 & $0.184^{* *}$ & 2.223 \\
Health impact & $0.218^{* * *}$ & 2.677 & $0.334^{* * *}$ & 3.177 \\
\hline Government & 0.040 & 0.538 & $0.082^{*}$ & 0.907 \\
technician & & & & \\
Neighbor & 0.099 & 1.309 & $0.085^{*}$ & 0.879 \\
Distributor & -0.078 & -0.959 & 0.197 & 1.775 \\
\hline Age & -0.001 & -0.142 & $-0.017^{* *}$ & -2.024 \\
Education & $0.052^{* *}$ & 2.389 & $0.090^{* * *}$ & 3.11 \\
Share of rice sale & $0.142^{* *}$ & 2.268 & 0.010 & 0.355 \\
\hline Constant & - & - & $-2.784^{* * *}$ & -2.623 \\
\hline Limit Points & & & - & - \\
LIMIT_2:C(12) & $2.044^{* * *}$ & 2.628 & & - \\
LIMIT_3:C(13) & $3.901^{* * *}$ & 4.916 & - & 327 \\
\hline Log likelihood & -296.3003 & & -185.3532 & \\
LR statistic & $55.05064^{* * *}$ & & & \\
Pseudo R-squared & 0.085000 & & & \\
McFadden & & & & \\
R-squared & & & & \\
\hline Observations & 723 & & & \\
\hline
\end{tabular}

Source: Authors' own estimates.

Notes: ${ }^{*},{ }^{* *}$ and ${ }^{* * *}$ indicate statistical significance at the level of $10 \%, 5 \%$ and $1 \%$.

\section{Conclusion}

As one of the main agricultural production provinces in central China, Anhui is the place where Chinese rural reform originated. This study explores farmers' willingness to grow GM BT rice prior to its commercial release in the case of Anhui using a survey database. The data were collected through face-to-face interviews. The sample consists of 723 farmers in the rice-planting regions, and the respondents are experienced rice farmers. Based on the descriptive analyses of the data, ordered and 
binary probit models are used to comparatively analyze the effect of expected benefits and risks, social pressures, and farmers' socioeconomic and rice-farming characteristics on their adoption decision toward GM BT rice.

This study shows that the farmers' knowledge of GM crops is very limited. Approximately $83.3 \%$ of the respondents are not aware of GM crops; with regard to their willingness to adopt GM rice, approximately $35.5 \%$ of the respondents are keen on adopting the new technology, and approximately $54.8 \%$ are uncertain whether or not to shift to growing GM BT rice. The farmers' socioeconomic and rice-farming characteristics show that the majority of the respondents are middle aged or old and less educated. Because of the small amount of rice acreage approximately $90.4 \%$ of the respondents are engaged in non-agricultural activities, and the majority of them earns an off-farming income which accounts for above $50 \%$ of the family income.

The results of the econometric models show that the ex ante adoption decision for GM BT rice is driven by output, crop management, health impact, seed price, and education level. This finding is robust across all the models. Higher output and income, greater simplicity in crop management, and lower health risk have a positive effect on the decision to adopt, and higher seed price has a negative effect. A higher educational level increases the probability of a farmer planting GM rice. A comparison between the two models demonstrates that farmers are more deliberate in the face of fewer choices. Aside from the above-mentioned variables, government technicians' recommendations, neighbors' attitudes, and fewer environmental risks also have a positive effect on the farmers' decision to adopt GM rice, whereas age has a negative effect in the probit model.

The findings in this study imply that farmers are of the characteristics of an "economic man". Therefore, the key to the adoption of GM crops is to ensure that farmers can gain economic benefits. It is of great interest to observe that health impact of GM crops also is a significant determinant of farmers' decision. This further verifies that farmers are moral economic men. 


\section{References:}

Areal, F.J., Riesgo, L., Gomez-Barbero, M. and Rodriguez-Cerezo, E. (2012), "Consequences of a coexistence policy on the adoption of GMHT crops in the European Union", Food Policy, Vol. 37, No.4, pp. 401-411.

Blazy, J.M., Carpentier, A. and Thomas, A. (2011), "The willingness to adopt agro-ecological innovations: application of choice modeling to Caribbean Banana planters", Ecological Economics, Vol.72, pp.140-150.

Breustedt, G., Muller-Scheebel, J. and Latacz-Lohmann, U. (2008), "Forecasting the adoption of GM oilseed rape: evidence from a discrete choice experiment in Germany", Journal of Agricultural Economics, Vol. 59, No.2, pp. 237-256.

Chong, M. (2005), "Perception of the risks and benefits of Bt eggplant by Indian farmers", Journal of Risk Research, vol. 8, pp. 617-634.

Consmuller, N., Beckmann, V. and Petrick, M. (2010), “An econometric analysis of regional adoption patterns of Bt maize in Germany", Agricultural Economics, Vol. 41, pp. 275-284.

Demont, M. and Stein, A.J. (2013), "Global value of GM rice: a review of expected agronomic and consumer benefits", New Biotechnology, Vol. 30, No. 5, pp. 426-436.

Finger, R., Hartmann, B. and Feitknecht, M. (2009), “Adoption patterns of Herbicide-Tolerant soybeans in Argentina”, Agbioforum, Vol. 12, pp. 404-411.

Greene, W.H. (2011), Econometric Analysis, sixth edition, China Renmin University Press, Beijing, China.

Guehlstorf, N.P. (2008), "Understanding the scope of farmer perceptions of risk: considering farmer opinions on the use of genetically modified (GM) crops as a stakeholder voice in policy", Journal of Agricultural and Environmental Ethics, Vol. 21, pp. 541-558.

Gyau, A., Voss, J., Spiller, A. and Enneking, U. (2009), "Farmers acceptance of genetically modified seeds in Germany: results of a cluster analysis", International Food and Agribusiness Management Review, Vol. 12, No. 4, pp. $61-79$. 
Hall, C. (2008), "Identifying farmer attitudes towards genetically modified (GM) crops in Scotland: are they pro- of anti-GM?" Geoforum, Vol. 39, No. 1, pp. 204-212.

Hou, L.K., Huang, J.K., Wang, X.B., Hu, R.F. and Xue, Ch.L. (2012), “Farmer's knowledge on GM technology and pesticide use: evidence from papaya production in China", Journal of Integrative Agriculture, vol. 11, No. 12, pp. 2107-2115.

Huang, J.K., Hu, R.F., Chen, R.J. Mi, J.W, Rozelle, S. and Pray, C. (2010), Economic Impact of Transgenic Biotechnology, Science Press, Beijing, China.

James, C. (2013), Global Status of Commercialized Biotech/GM crops: 2013. ISAAA Brief, No. 46, Ithaca, NY.

James, D.G., Jier, E.H, Willian, A.K. Nigulas, P., Mani, D.P. (2003), The Economics of Biotechnology(Chinese edition), Shanghai People's Publishing House, Shanghai, China.

Keelan, C., Thorne, F.S., Flanagan, P., Newman, C. and Mullins, E. (2009), "Predicted willingness of Irish farmers to adopt GM technology", Agbioforum, Vol. 12, pp. 394-403.

Krishna, V.V, Qaim, M. (2007), "Estimating the adoption of BT eggplant in India: who benefits from public-private partnership", Food Policy, Vol. 32, pp. 523-543.

Liu, X.X. and Yu, D.W. (2010), “An investigation and analysis of the farmers' cognitive status of GM seeds market in China", Journal of Huazhong Agricultural University (Social Sciences Edition), No.1, pp. 21-26.

Qaim, M., Pray, C.E. and Zilberman, D. (2008), "Economic and social considerations in the adoption of BT crops", Integration of Insect-Resistant Genetically Modified Crops within IPM Programs, Vol. 5, pp. 329-356.

Sausse, C., Bail, M.L., Lecroart, B., Remy, B. and Messean, A. (2013), "How to manage the coexistence between genetically modified and conventional crops in grain and oilseed collection areas? Elaboration of scenarios using role playing games", Land use Policy, No. 30, pp. 719-729.

Skevas, T., Fevereiro, P. and Wesseler, J. (2010), "Coexistence regulations and 
agriculture production: a case study of five Bt maize producers in Portugal", Ecological Economics, Vol. 69, No.12, pp. 2402-2408.

Sun, G.Q., Jin, W.J., Wan, Y.S. and Lin, M. (2010), "Research progress and analysis of industrialization on transgenic rice in China", Biotechnology Bulletin, No.12, pp.1-6.

Wang, S.G. and Liu, X.Zh. (1996), “An analysis of poor farmers behavior to accept new technology under the condition of incomplete information", Agricultural Economy Issues, No.12, pp. 31-36.

Xu, J.P. and Yan, Zh.Y. (2010), "Farmers' cognition of transgenic technology and production intention of transgenic staple foods", Science Forum in China, No.11, pp.142-148.

Xu, R.M., Luan, J.D. and Li, T.T. (2012), “An analysis of the development strategy of genetically modified crops in China: from the perspectives of stakeholders", Journal of Convergence Information Technology, Vol. 7, No. 23, pp.680-688.

Zhan, J.T., Wu, Y.R., Zhang, X.H. and Zhou, Zh.Y. (2012), "Why do farmers quit from grain production in China? causes and implications", China Agricultural Economic Review, Vol. 4, No.3, pp. 342-362.

Zhou, J.H. (2006), “An analyses of farmers vegetables quality and safety control behavior and influential factors", Chinese Rural Economy, No.11, pp. 25-34. 